KEDOKTERAN DAN KESEHATAN

\title{
Peningkatan Pengetahuan Upaya Kesehatan Masyarakat pada Dokter Internsip Berdasarkan Faktor Wahana Puskesmas
}

\author{
Rofingatul Mubasyiroh ${ }^{1}$, Mieska Despitasari ${ }^{2}$, Harimat Hendarwan ${ }^{3}$ \\ 1,2,3 Badan Penelitian dan Pengembangan Kesehatan, Kementerian Kesehatan Republik Indonesia \\ Jalan Percetakan Negara No.29, Johar Baru, Kota Jakarta Pusat, DKI Jakarta 10560 \\ Email: rofi.litbang@gmail.com
}

\begin{abstract}
ABSTRAK
Program internsip merupakan proses pemantapan mutu profesi dokter. Proses pemahiran dan penyelarasan hasil pendidikan dengan praktik di lapangan berupa pemahiran upaya kesehatan perorangan (UKP) selama 8 bulan, dan upaya kesehatan masyarakat (UKM) selama 4 bulan. Pendidikan kedokteran berbasis komunitas merupakan wujud perubahan paradigma dari kuratif menjadi preventif. Tulisan ini menganalisis perubahan pengetahuan peserta internsip tentang UKM. Data yang digunakan adalah hasil penelitian internsip tahun 2015. Penelitian menggunakan pendekatan kualitatif dan kuantitatif dengan disain longitudinal study. Pengumpulan data dilakukan pada bulan Maret 2015 dan Oktober 2015 di provinsi yang terpilih berdasarkan status akreditasi dan status kepemilikan Fakultas Kedokteran. Instrumen penelitian berupa kuesioner kuantitatif. Analisis data secara deskriptif dan dilakukan uji $\mathrm{T}$ untuk mengetahui faktor yang menunjukkan perbedaan peningkatan pengetahuan tentang UKM. Secara umum terjadi peningkatan nilai pengetahuan peserta internsip tentang UKM. Faktor yang menunjukkan perbedaan adalah lama puskesmas menjadi wahana internsip, keberadaan perpustakaan puskesmas, keberadaan pusling roda empat, pendamping menilai logbook, pendamping menilai laporan, pendamping memiliki cukup waktu dalam membimbing, dan kegiatan mini project yang diikuti peserta. Diperlukan dukungan sarana, optimalisasi pendampingan dan peran aktif peserta untuk lebih meningkatkan pengetahuan UKM.
\end{abstract}

Kata kunci: pengetahuan UKM, internsip, wahana puskesmas

\section{Public Health Efforts Knowledge Improvement Based On Public Health Centre Elements of Internship Program}

\begin{abstract}
Internship program is a process of quality assurance of the medical doctor profession. The process of understanding and aligning educational outcomes with reality in the form of individual health efforts (UKP) for 8 months and public health efforts (UKM) for 4 months. Community-based medical education is a form of paradigm reform from curative into preventive efforts. This article analyzes changes in interns' knowledge about UKM. Data from a longitudinal study (Indonesian Study of Internship Doctor, 2015) were used, which was collected quantitatively and qualitatively. The data collection was conducted in March and October 2015 in the province were selected based on their accreditation status and the status of ownership of faculty of medicine. The researchinstrument is structured quantitative questionnaires. Descriptive data analysis and T-test were done to determine the factors that indicate increased knowledge about differences in public health efforts. Generally, intern's knowledge UKM was increased. Factors that showed difference
\end{abstract}


were public health centres that became the place of internsip program, library and four wheels ambulance existence, preceptor who assessed logbook and report, preceptor who gave enough time for supervising, and mini projects followed by interns. It is necessary to optimize supervising and the active role of the interns'.

Keywords: knowledge in public health efforts, internship, public health centre environment

\section{Pendahuluan}

Undang-Undang Nomor 36 tahun 2009 tentang Kesehatan, menyebutkan bahwa setiap orang mempunyai hak dalam memperoleh pelayanan kesehatan yang aman, bermutu, dan terjangkau (pasal 5 ayat 2). Dalam hal ini negara bertanggung jawab atas ketersediaan segala bentuk upaya kesehatan yang bermutu, aman, efisien, dan terjangkau (pasal 19). Pelayanan kesehatan yang bermutu sangat erat kaitannya dengan profesionalisme dan kualitas pemberi/ pelaksana pelayanan kesehatan ${ }^{1}$.

Dokter merupakan salah satu tenaga kesehatan utama yang menjadi ujung tombak dalam pelayanan kesehatan. Seorang dokter dituntut untuk memberikan pelayanan bermutu tinggi, profesional dan mengutamakan keselamatan pasien karena berkaitan erat dengan fisik dan jiwa manusia. Dalam kaitan untuk memberikan perlindungan pada masyarakat atas tindakan pelayanan yang diberikan oleh dokter, dibutuhkan dokter yang mampu menerapkan kompetensi secara bertanggungjawab dan mengutamakan keselamatan pasien.

Sesuai dengan Standar Pendidikan Profesi Dokter Indonesia, setelah menjalani pendidikan tahap sarjana kedokteran selama 7 semester, pendidikan dilanjutkan ke tahap profesi selama minimal 3 semester.
Selanjutnya dokter yang baru lulus pendidikan, belum dapat langsung melakukan praktik mandiri, diperlukan suatu proses pemahiran dan pemandirian melalui proses internsip ${ }^{2}$.

Internsip adalah proses pemagangan bagi dokter baru lulus pendidikan, yang telah memiliki ijazah dan telah melakukan sumpah dokter sebelum dokter tersebut berpraktik mandiri. Dalam program ini, seorang dokter akan bekerja melayani pasien dibawah pendampingan dokter yang lebih senior. Program internsip dilaksanakan di fasyankes yang telah ditetapkan sebagai wahana Internsip, selama 12 bulan ( 8 bulan di RS dan 4 bulan di puskesmas). Wahana adalah sarana pelayanan kesehatan yang menjadi tempat pelaksanaan program internsip yang telah memenuhi kriteria sebagai wahana internsip ${ }^{3}$. Pada tahap ini dokter muda tersebut dapat menerapkan kompetensi yang diperoleh selama pendidikan secara terintegrasi, komprehensif, serta mandiri dalam rangka pemahiran, pemandirian dan penyelarasan antara hasil pendidikan dengan praktik di lapangan.

Pengetahuan timbul setelah seseorang melakukan penginderaan terhadap suatu objek tertentu. Tanpa pengetahuan, seseorang tidak mempunyai 
Rofingatul Mubasyiroh, Mieska Despitasari, Harimat Hendarwan, Peningkatan Pengetahuan Upaya Kesehatan Masyarakat pada Dokter Internsip Berdasarkan Faktor Wahana Puskesmas

dasar untuk mengambil keputusan dan menentukan tindakan terhadap masalah yang dihadapi ${ }^{4}$. Saat seorang dokter dihadapkan pada sebuah masalah kesehatan, maka pengambilan keputusan atau tindakan yang akan dilakukan harus didasari oleh pengetahuan yang dimiliki.

Program Internsip Dokter Indonesia telah dilaksanakan sejak tahun 2010. Saat ini Program Internsip telah memasuki tahun ke-

4. Sampai dengan Oktober tahun 2015, sebanyak 19.671 dokter berpartisipasi dalam program Internsip, sebanyak 13.482 dokter diantaranya telah selesai melaksanakan Internsip, sementara itu 6.189 dokter tengah melaksanakan Internsip ${ }^{5}$. Salah satu lingkup kegiatan peserta internsip di wahana adalah melakukan kegiatan kesehatan masyarakat baik di dalam maupun di luar gedung. Kegiatan ini terutama dilakukan di puskesmas.

Tiga prinsip kesehatan masyarakat yang harus dimasukkan ke dalam kurikulum pendidikan dokter adalah 1) pelatihan, kualitas dan kuantitas dokter harus dapat memenuhi kebutuhan masyarakat terhadap kesehatan; 2) dokter memiliki kewajiban sosial untuk mencegah penyakit dan mempromosikan kesehatan, dan pelatihan medis harus mencakup pengetahuan yang luas untuk memenuhi kewajiban tersebut; 3) kolaborasi antara teori pengobatan dan kesehatan masyarakat di komunitas menghasilkan keuntungan bagi keduanya ${ }^{6}$.
Program internsip adalah proses pemantapan mutu profesi dokter untuk menerapkan kompetensi yang diperoleh selama pendidikan, secara terintegrasi, komprehensif, mandiri serta menggunakan pendekatan kedokteran keluarga dalam rangka pemahiran dan penyelarasan antara hasil pendidikan dengan praktik di lapangan. Program Internsip memberikan kesempatan kepada dokter baru lulus Program Studi Pendidikan Dokter berbasis kompetensi untuk menerapkan serta mempraktikkan kompetensi yang diperoleh selama pendidikan dalam rangka penyelarasan antara hasil pendidikan dan praktik di lapangan merupakan tujuan Program Internsip Dokter Indonesia. Dari sisi pengembangan SDM, program internsip dokter akan memberikan kesempatan kepada dokter untuk mendapatkan pengalaman yang meliputi pengalaman melakukan upaya kesehatan perorangan (UKP) selama 8 bulan, dan upaya kesehatan masyarakat (UKM) selama 4 bulan. Pengalaman ini akan membantu para dokter melihat upaya pelayanan secara komprehensif.

Pentingnya pendidikan kedokteran berbasis komunitas di kurikulum sarjana kedokteran telah divalidasi dalam Pendidikan Kedokteran, termasuk di Indonesia. Perubahan paradigma dari kuratif menjadi preventif telah membuat pendidikan kedokteran berbasis komunitas menjadi sangat penting. Sebagian kecil lulusan 
dokter akan memilih Kesehatan Masyarakat atau Komunitas sebagai spesialisasinya, akan tetapi kurikulum sarjana kedokteran yang lengkap mengenai kesehatan masyarakat adalah keadaan yang esensiil untuk seluruh dokter ${ }^{7}$. Ilmu kesehatan masyarakat merupakan kompetensi yang sangat penting bagi seorang dokter, terutama pada layanan primer $^{8}$. Layanan primer merupakan pertama kali pasien atau masyarakat masuk ke dalam suatu sistem pelayanan kesehatan profesional dan juga memberikan pelayanan kesehatan yang komprehensif, yang tidak hanya mementingkan kuratif, melainkan juga preventif dan promotif. Pentingnya ilmu kesehatan masyarakat akibat perubahan pelayanan dari kuratif menjadi preventif disebutkan dalam Standar Kompetensi Dokter Indonesia (SKDI) $2012^{9}$.

Oleh karenanya, kemampuan dokter internsip dalam upaya kesehatan masyarakat sama pentingnya dengan kemampuan upaya kesehatan perorangan. Puskesmas merupakan wahana yang diperlukan untuk meningkatkan kemampuan peserta internsip terkait upaya keseatan masyarakat. Berdasarkan PMK No.75 tahun 2014, Upaya kesehatan di puskesmas terbagi menjadi upaya kesehatan perseorangan tingkat pertama dan upaya kesehatan masyarakat tingkat pertama. Upaya Kesehatan Masyarakat (UKM) adalah setiap kegiatan untuk memelihara dan meningkatkan kesehatan serta mencegah dan menanggulangi timbulnya masalah kesehatan dengan sasaran keluarga, kelompok, dan masyarakat.

Selain bermanfaat untuk peserta internsip, pelaksanaan internsip di Puskesmas juga berpengaruh terhadap derajat kesehatan masyarakat sekitar. Jejaring dengan tenaga kesehatan setempat dapat meningkatkan kepercayaan diri, kesadaran masyarakat secara umum tentang kesehatan dan pada akhirnya terhadap pemanfaatan fasilitas $\operatorname{kesehatan}^{10}$. Oleh karena itu, tulisan ini menganalisis perubahan pengetahuan peserta internsip tentang Upaya Kesehatan Masyarakat.

\section{Metode Penelitian}

Data yang digunakan dalam analisis artikel ini adalah data hasil penelitian internsip tahun 2015. Penelitian tersebut menggunakan pendekatan kualitatif dan kuantitatif dengan disain longitudinal study. Pengumpulan data dilakukan dua kali, yaitu pada bulan maret 2015, saat peserta internsip mulai menjalani program internsip (tahap pre). Selanjutnya tahap kedua (post) yaitu saat peserta telah menjalani program internsip selama 6-7 bulan (di Puskesmas dan RS), pada bulan Oktober 2015.

Pemilihan wilayah penelitian dilakukan secara random dengan mempertimbangkan status akreditasi Fakultas Kedokteran daripeserta internsip dan status kepemilikan Fakultas Kedokteran peserta internsip baik pemerintah maupun 
Rofingatul Mubasyiroh, Mieska Despitasari, Harimat Hendarwan, Peningkatan Pengetahuan Upaya Kesehatan Masyarakat pada Dokter Internsip Berdasarkan Faktor Wahana Puskesmas

DOI : $10.24853 /$ jkk.14.1.26-38

swasta. Penelitian dilakukan di provinsi Bengkulu, DKI Jakarta, Jawa Barat, Jawa Timur, Kalimantan Timur, Sulawesi Selatan, Nusa Tenggara Timur, Papua Barat, dan Papua. Populasi penelitian adalah dokter peserta Program Internsip. Sementara sampelnya adalah peserta internsip di wilayah terpilih yang telah menjalani program internsip di puskesmas pada tahun 2015.

Instrumen penelitian yang digunakan adalah kuesioner kuantitatif terstruktur. Kuesioner kuantitatif digunakan untuk mengumpulkan data pada tahap pre dan post dari peserta internsip, pendamping, dan pimpinan wahana puskesmas. Data pengetahuan berupa skor jawaban dari 60 pertanyaan pengetahuan upaya kesehatan masyarakat. Data yang dianalisis dalam artikel ini adalah data yang terkait dengan peserta internsip berupa pengetahuan tentang upaya kesehatan masyarakat, kegiatan yang dilakukan oleh peserta internsip, dan penilaian peserta internsip terhadap pembimbingan oleh pendamping. Data yang terkait dengan pendamping internsip adalah lama menjadi dokter dan manajemen pendampingan. Data yang terkait dengan wahana berupa jenis puskesmas, jumlah ruangan pendukung, dan sarana kendaraan.

Analisis dilakukan secara deskriptif untuk melihat gambaran kondisi faktor sarana wahana, pendamping dan kegiatan peserta serta capaian penilaian terhadap pengetahuan peserta. Delta pengetahuan peserta memiliki sebaran data normal, sehingga dilakukan uji $\mathrm{T}$ untuk mengetahui faktor yang menunjukkan perbedaan peningkatan pengetahuan peserta internsip tentang upaya kesehatan masyarakat.

\section{Hasil}

Tabel 1. Distribusi Peserta Internsip Berdasarkan Wilayah Penempatan

\begin{tabular}{|c|c|c|c|c|}
\hline \multirow{2}{*}{ Provinsi } & \multirow{2}{*}{ Kabupaten/Kota } & \multirow{2}{*}{ Nama Puskesmas } & \multicolumn{2}{|c|}{ Jenis Kelamin } \\
\hline & & & Laki-laki & Perempuan \\
\hline Bengkulu & Muko-Muko & Ipuh & $5(35.7 \%)$ & $9(64.3 \%)$ \\
\hline DKI Jakarta & Jakarta Utara & Utan Panjang & $2(28.6 \%)$ & $5(71.4 \%)$ \\
\hline Jawa Barat & Cianjur & Muka & $8(57.1 \%)$ & $6(42.9 \%)$ \\
\hline Jawa Timur & Blitar & Kepanjen Kidul & $3(27.3 \%)$ & $8(72.7 \%)$ \\
\hline Kalimantan Timur & Kutai Barat & Barong Tongkok & $8(57.1 \%)$ & $6(42.9 \%)$ \\
\hline \multirow[t]{2}{*}{ Sulawesi Selatan } & Luwu Timur & Malili & $4(30.8 \%)$ & $9(69.2 \%)$ \\
\hline & Wajo & Salobulo & $7(50.0 \%)$ & $7(50.0 \%)$ \\
\hline NTT & Sikka & Beru & $4(33.3 \%)$ & $8(66.7 \%)$ \\
\hline Papua Barat & Kota Sorong & Remu & $4(57.1 \%)$ & $3(42.9 \%)$ \\
\hline Papua & Biak Numfor & Yendidori & $3(33.3 \%)$ & $6(66.7 \%)$ \\
\hline Total & & & $48(41.7 \%)$ & $67(58.3 \%)$ \\
\hline
\end{tabular}




\section{Peserta}

Jumlah responden kajian ini adalah 115 orang, $58.3 \%$ diantaranya adalah perempuan. Berdasarkan distribusinya, responden kajian terbanyak terdapat di provinsi Bengkulu, Jawa Barat, Kalimantan Timur, dan Sulawesi Selatan dimana jumlah peserta di masing-masing puskesmas adalah sekitar 12\% (Tabel 1).

Belum seluruh responden melaksanakan kegiatan terkait Upaya Kesehatan Masyarakat (UKM). Secara keseluruhan, posyandu adalah kegiatan terkait UKM yang paling banyak dilaksanakan oleh responden kajian (ratarata $13.49 \pm 14.445$ ) dan KIA-KB (rata-rata $11.71 \pm 12.527)$. Sementara kegiatan terkait UKM yang paling sedikit dilaksanakan oleh responden adalah mini project dengan ratarata $1.51 \pm 1.518$ (Tabel 2).

Masih adanya peserta yang belum melaksanakan kegiatan tertentu terkait UKM menunjukkan bahwa belum seluruh materi terkait UKM di puskesmas diperoleh peserta dan hal ini dapat berdampak pada tidak komprehensifnya pengetahuan terkait UKM yang diperoleh peserta.

Tabel 2. Rata-Rata Capaian Kegiatan Peserta Internsip Yang Terkait Upaya Kesehatan Masyarakat

\begin{tabular}{|c|c|c|c|c|c|}
\hline Capaian Jumlah Kegiatan Peserta & $\mathbf{N}$ & Minimum & Maksimum & Mean & Std. Deviasi \\
\hline Kegiatan posyandu & 115 & 0 & 90 & 13.49 & 14.445 \\
\hline $\begin{array}{l}\text { Kegiatan Upaya Promosi Kesehatan dan } \\
\text { Pemberdayaan Masyarakat (misalnya } \\
\text { penyuluhan massal) }\end{array}$ & 115 & 0 & 21 & 6.23 & 5.626 \\
\hline $\begin{array}{l}\text { Kegiatan Upaya Kesehatan } \\
\text { Lingkungan }\end{array}$ & 112 & 0 & 30 & 4.77 & 6.033 \\
\hline $\begin{array}{l}\text { Kegiatan Upaya Kesehatan Ibu dan } \\
\text { Anak (KIA) serta Keluarga Berencana } \\
\text { (KB) }\end{array}$ & 115 & 0 & 60 & 11.71 & 12.527 \\
\hline $\begin{array}{l}\text { Kegiatan Upaya Perbaikan Gizi } \\
\text { Masyarakat }\end{array}$ & 111 & 0 & 55 & 5.91 & 7.978 \\
\hline $\begin{array}{l}\text { Kegiatan Upaya surveillance, } \\
\text { Pencegahan dan Pemberantasan }\end{array}$ & 113 & 0 & 50 & 5.88 & 8.775 \\
\hline $\begin{array}{l}\text { Penyakit Menular dan Tidak Menular } \\
\text { Kegiatan mini project }\end{array}$ & 115 & 0 & 10 & 1.51 & 1.518 \\
\hline
\end{tabular}

Tabel 3. Karakteristik Puskesmas yang terkait Kegiatan Upaya Kesehatan Masyarakat (N=115)

\begin{tabular}{lcccc}
\hline \multicolumn{1}{c}{ Karakteristik Puskesmas } & Minimum & Maximum & Mean & Std. Deviation \\
\hline Lama menjadi wahana (tahun) & 0 & 3 & 0.76 & 1.246 \\
Jumlah ruang perpustakaan & 0 & 1 & 0.22 & 0.414 \\
Jumlah ruang diskusi & 0 & 1 & 0.65 & 0.478 \\
Jumlah ambulans & 0 & 4 & 1.05 & 1.154 \\
Jumlah kendaraan roda 4 & 0 & 1 & 0.28 & 0.450 \\
Jumlah pusling roda 4 & 0 & 4 & 0.79 & 1.151 \\
Jumlah kendaraan roda 4 lain & 0 & 1 & 0.11 & 0.318 \\
Jumlah kendaraan roda 2 & 1 & 14 & 8.06 & 3.597 \\
Jumlah perahu & 0 & 0 & 0.00 & 0.000 \\
\hline
\end{tabular}


Rofingatul Mubasyiroh, Mieska Despitasari, Harimat Hendarwan, Peningkatan Pengetahuan Upaya Kesehatan Masyarakat pada Dokter Internsip Berdasarkan Faktor Wahana Puskesmas

DOI : $10.24853 /$ jkk.14.1.26-38

\section{Wahana}

Wahana yang dimaksud dalam tulisan ini adalah puskesmas yang merupakan lokasi penempatan peserta Internsip. Peserta menjalani program Internsip selama 4 bulan di puskesmas. Sejumlah $45.2 \%$ responden ditempatkan di puskesmas non-perawatan dan lainnya $(54.8 \%$ ) di puskesmas perawatan (Tabel 3).

Tabel 3 menunjukkan bahwa responden penelitian ditempatkan pada puskesmas yang sudah 1 tahun menjadi wahana internsip. Responden hampir tidak memperoleh akses terhadap perpustakaan dan kendaraan roda 4 di wahana. Lebih dari separuh responden ditempatkan pada puskesmas yang memiliki ruang diskusi. Responden ditempatkan di puskesmas yang memiliki minimal satu kendaraan roda dua dan maksimal 14 kendaraan roda dua. Tidak ada responden yang ditempatkan di puskesmas yang memiliki perahu.

\section{Pendamping}

Tabel 4 menunjukkan bahwa peserta yang menjadi responden penelitian didampingi oleh pendamping yang rata-rata sudah berpengalaman menjadi dokter 20 tahun, mendampingi 9 peserta dan mendampingi peserta 6 kali selama sebulan. Sementara tabel 5 menunjukkan jenis dan frekuensi pelaksanaan pendampingan oleh pendamping. Lebih dari $85 \%$ responden didampingi oleh pendamping yang menyususn jadwal kegiatan peserta dan melakukan penilaian terhadap logbook. Masih ada sekitar 24-30\% responden yang didampingi oleh pendamping yang belum melakukan penilaian terhadap laporan kasus dan kinerja peserta.

Tabel 4. Karakteristik Pendamping Internsip

\begin{tabular}{lcccc}
\hline \multicolumn{1}{c}{ Karakteristik Pendamping } & Minimum & Maksimum & Mean & Std. Deviasi \\
\hline Lama menjadi dokter (tahun) & 6 & 36 & 20.435 & 13.100 \\
Jumlah peserta yang didampingi & 4 & 21 & 9.078 & 5.387 \\
Frekuensi pendampingan dalam satu bulan & 1 & 24 & 6.391 & 7.306 \\
\hline
\end{tabular}

Tabel 5. Pelaksanaan Pendampingan oleh Pendamping

\begin{tabular}{lcccc}
\hline \multirow{2}{*}{ Kegiatan Pendamping } & \multicolumn{2}{c}{ Ya } & \multicolumn{2}{c}{ Tidak } \\
\cline { 2 - 5 } & $\mathbf{n}$ & $\mathbf{\%}$ & $\mathbf{n}$ & $\mathbf{\%}$ \\
\hline Menyusun jadwal kegiatan peserta & 99 & 86.1 & 16 & 13.9 \\
Menilai kinerja peserta & 81 & 70.4 & 34 & 29.6 \\
Menilai logbook & 101 & 87.8 & 14 & 12.2 \\
Menilai laporan kasus & 87 & 75.7 & 28 & 24.3 \\
\hline
\end{tabular}

Tabel 6. Skor Pengetahuan UKM Peserta Internsip

\begin{tabular}{|c|c|c|c|c|c|}
\hline & $\mathbf{N}$ & Minimum & Maksimum & Mean & Std. Deviasi \\
\hline $\begin{array}{l}\text { Skor Pengetahuan UKM (pre- } \\
\text { test) }\end{array}$ & 115 & 10 & 25 & 18.98 & 2.800 \\
\hline $\begin{array}{l}\text { Skor Pengetahuan UKM (post- } \\
\text { test) }\end{array}$ & 115 & 21 & 40 & 29.65 & 4.554 \\
\hline $\begin{array}{l}\text { Perubahan Skor Pengetahuan } \\
\text { UKM }\end{array}$ & 115 & -1 & 25 & 10.67 & 4.744 \\
\hline
\end{tabular}


Hampir seluruh peserta (99.1\%), menyatakan bahwa pendamping memiliki kompetensi yang baik dan secara umum bersahabat dalam membimbing peserta. Masih ada $1.7 \%$ peserta yang menyatakan bahwa akses komunikasi dengan pendamping kadang-kadang sulit. Sebanyak 91.3\% peserta menyatakan bahwa pendamping memiliki cukup waktu dalam membimbing peserta dan membantu peserta dalam memecahkan masalah medik. Sejumlah $10.4 \%$ peserta menyatakan bahwa pendamping jarang atau tidak sama sekali membantu peserta memecahkan masalah sosial/kesehatan masyarakat. Demikian pula halnya $13 \%$ peserta menyatakan bahwa pendamping jarang atau sama sekali tidak memberikan umpan balik terhadap aktifitas peserta.

Tabel 6 menunjukkan bahwa ratarata skor pengetahuan UKM peserta di awal program (pre-test) adalah 18.98 dan setelah 6-7 bulan menjalani internsip (post-test) rata-rata skor meningkat sebesar 10.67 poin. Namun demikian, rata-rata skor post-test baru mencapai $50 \%$ nilai maksimal yang diharapkan. Total skor apabila peserta menjawab dengan benar seluruh pertanyaan adalah 60 .

\section{Perbedaan Peningkatan Pengetahuan Peserta Internsip tentang Upaya Kesehatan Masyarakat}

Berdasarkan uji normalitas, selisih pengetahuan peserta internsip tentang upaya kesehatan masyarakat terdistribusi normal. Variabel yang diuji adalah selisih skor pengetahuan upaya kesehatan masyarakat dengan beberapa variabel kondisi wahana, pendamping dan peserta. Hasil uji $\mathrm{T}$ menunjukkan tujuh faktor yang memiliki perbedaan bermakna dalam peningkatan pengetahuan peserta internsip tentang upaya kesehatan masyarakat, yaitu lama menjadi wahana, keberadaan perpustakaan, keberadaan pusling roda empat, pendamping menilai log book peserta, pendamping menilai laporan peserta, pendamping memiliki cukup waktu dalam membimbing serta jumlah kegiatan mini project yang diikuti peserta (Tabel 7).

Peserta yang ditempatkan di puskesmas yang $<2$ tahun menjadi wahana internsip memiliki rata-rata peningkatan nilai $(11.35 \pm 4.75)$ lebih tinggi dari peserta yang ditempatkan di puskesmas yang sudah $\geq 2$ tahun menjadi wahana. Hal ini berbeda dengan keberadaan perpustakaan di puskesmas. Peserta yang memiliki akses perpustakaan di puskesmas memiliki ratarata nilai $(12.48 \pm 4.89)$ lebih tinggi dari peserta yang tidak dapat mengakses perpustakaan di puskesmas $(10.17 \pm 4.60)$. Kepemilikan pusling roda empat di puskesmas secara tidak langsung juga mempengaruhi rata-rata nilai pengetahuan UKM peserta $(11.62 \pm 4.50)$ yang lebih tinggi dibandingkan peserta yang berada di puskesmas yang tidak memiliki pusling roda empat $(9.70 \pm 4.83)$. 
Rofingatul Mubasyiroh, Mieska Despitasari, Harimat Hendarwan, Peningkatan Pengetahuan Upaya Kesehatan Masyarakat pada Dokter Internsip Berdasarkan Faktor Wahana Puskesmas

DOI : $10.24853 /$ jkk.14.1.26-38

Tabel 7. Distribusi Rata-Rata Peningkatan Pengetahuan Upaya Kesehatan Masyarakat Menurut Beberapa Faktor

\begin{tabular}{|c|c|c|c|c|}
\hline Faktor & Kategori & $\mathbf{n}$ & Rata-rata \pm SD & $p$ \\
\hline \multirow[t]{2}{*}{ Lama menjadi wahana } & $\geq 2$ tahun & 26 & $8.35 \pm 4.00$ & 0.004 \\
\hline & $<2$ tahun & 89 & $11.35 \pm 4.75$ & \\
\hline \multirow[t]{2}{*}{ Perpustakaan } & Ada & 25 & $12.48 \pm 4.89$ & 0.030 \\
\hline & Tidak ada & 90 & $10.17 \pm 4.60$ & \\
\hline \multirow[t]{2}{*}{ Pusling roda empat } & Ada & 58 & $11.62 \pm 4.50$ & 0.029 \\
\hline & Tidak ada & 57 & $9.70 \pm 4.83$ & \\
\hline \multirow[t]{2}{*}{ Menilai logbook peserta } & Ya & 101 & $11.26 \pm 4,58$ & 0.000 \\
\hline & Tidak & 14 & $6.43 \pm 3.72$ & \\
\hline \multirow[t]{2}{*}{ Menilai laporan peserta } & $\mathrm{Ya}$ & 87 & $11.37 \pm 4.54$ & 0.005 \\
\hline & Tidak & 28 & $8.50 \pm 4.80$ & \\
\hline \multirow{2}{*}{$\begin{array}{l}\text { Pendamping memiliki cukup } \\
\text { waktu dalam membimbing }\end{array}$} & Selalu cukup & 105 & $11.00 \pm 4.73$ & 0.015 \\
\hline & $\begin{array}{l}\text { Sering tidak cukup dan } \\
\text { hanya beberapa kali }\end{array}$ & 10 & $7.20 \pm 3.43$ & \\
\hline \multirow[t]{2}{*}{ Jumlah kegiatan mini project } & Cukup & 22 & $8.09+4.12$ & 0.004 \\
\hline & Kurang & 93 & $11.28+4.70$ & \\
\hline
\end{tabular}

Peserta dengan pendamping yang aktif menilai $\log$ book, peserta dengan pendamping yang aktif menilai laporan peserta, dan peserta dengan pendamping yang memiliki cukup waktu dalam membimbing, memiliki rata-rata peningkatan pengetahuan UKM yang lebih tinggi daripada peserta yang tidak didampingi pendamping dengan karakteristik tersebut. Dari sisi peserta, sebagian besar masih kurang mengikuti kegiatan mini project di puskesmas. Namun, peserta yang kurang mengikuti mini project memiliki rata-rata lebih tinggi $(11.28 \pm 4.70)$ dari peserta yang sudah cukup mengikuti kegiatan mini project di puskesmas $(8.09 \pm$ 4.12).

Pengetahuan dapat dipengaruhi oleh faktor internal, eksternal, dan upaya belajar. Faktor internal, misalnya intelegensia, minat, dan kondisi fisik. Faktor eksternal,

\section{Pembahasan}

Secara umum, terjadi peningkatan pengetahuan peserta terkait UKM. Namun, skornya masih sekitar 50\%. Perlu analisis lebih lanjut apakah hal tersebut terkait dengan belum dilaksanakannya seluruh jenis kegiatan UKM puskesmas oleh peserta, sehingga dapat menyebabkan kurang komprehensifnya pengetahuan UKM yang diperoleh peserta. Sementara itu, waktu kelulusan, persepsi tunjangan hidup, penerimaan internsip, adaptasi, jumlah dan jenis kasus upaya kesehatan masyarakat, peran dokter pendamping, kedisiplinan, komunikasi dan pilihan tindakan berpengaruh terhadap kinerja dokter internsip ${ }^{11}$. misalnya: keluarga, masyarakat dan sarana. Sementara faktor upaya belajar, misalnya strategi dan metode dalam pembelajaran ${ }^{4}$. 
Keberadaan sarana prasarana di puskesmas (sebagai faktor eksternal) secara tidak langsung mempengaruhi kemampuan peserta dalam proses pembelajaran. Peserta yang ditempatkan di puskesmas yang memiliki puskesmas keliling (pusling) mengalami peningkatan pengetahuan yang lebih tinggi. Hal ini terjadi karena puskesmas yang memiliki pusling dimungkinkan untuk melaksanakan kegiatan UKM luar gedung dengan frekuensi yang lebih tinggi. Dengan demikian, peserta internsip di puskesmas tersebut juga dimungkinkan lebih sering mengikuti kegiatan UKM puskesmas, sehingga pengetahuan UKM-nya pun meningkat. Pusling dalam hal ini merupakan alat bantu pelaksanaan pembelajaran UKM. Sehingga hasil kajian ini memperkuat pendapat bahwa alat bantu belajar merupakan faktor yang berperan dalam proses pembelajaran, dan dengan sendirinya berperan dalam peningkatan hasil belajar ${ }^{12}$.

Secara umum perpustakaan dapat berfungsi dalam pendidikan dan sumber informasi. Perpustakaan dapat menjadi tempat belajar dan menyiapkan informasi sebagai bahan referensi dalam mencari informasi. Perpustakaan menjadi bagian dari sarana penunjang kegiatan internship. Para peserta Internship menghimpun informasi dalam berbagai bentuk format sumber informasi, dan sumber ilmu pengetahuan lainnya. Perpustakaan secara umum memiliki beberapa peran antara lain sebagai penyedia sarana atau tempat untuk menghimpun informasi dari berbagai sumber untuk dikoleksi, selain itu perpustakaan juga berperan sebagi pusat penelitian, rekreasi dan aktifitas ilmiah lainnya ${ }^{13}$ Peserta yang memiliki akses terhadap perpustakaan mengalami peningkatan pengetahuan yang lebih baik. Hal ini mendukung pendapat bahwa faktor materi (bahan belajar) termasuk ke dalam faktor yang mempengaruhi proses belajar. Dengan proses belajar yang baik, peserta internsip dapat memperoleh input yang baik sehingga terjadi peningkatan pengetahuan UKM yang baik pula ${ }^{12}$.

Pendamping adalah dokter umum yang sudah mendapatkan pelatihan pendamping dari KIDI. Pendamping merupakan seorang dokter umum, kecuali jika dokter spesialis yang diangkat menjadi pendamping internsip. Pendamping berperan sebagai seorang "pengayom" yang berperan dalam mengenali kelebihan dan kekurangan peserta, dan memberikan umpan balik untuk membantu peserta mencapai tujuan PIDI. Seorang pendamping yang baik, sesuai dengan peraturan PIDI, harus bertindak bijaksana dalam menuntun dokter yang baru lulus untuk memahirkan kompetensinya ${ }^{13}$.

Pengajar, dalam hal ini pendamping, termasuk metode pendampingan yang tepat dapat meningkatkan pengetahuan UKM peserta internsip. Penilaian yang dilakukan pendamping terhadap logbook dan laporan 
Rofingatul Mubasyiroh, Mieska Despitasari, Harimat Hendarwan, Peningkatan Pengetahuan Upaya Kesehatan Masyarakat pada Dokter Internsip Berdasarkan Faktor Wahana Puskesmas

DOI : $10.24853 /$ jkk.14.1.26-38

peserta internsip merupakan sebuah

feedback bagi peserta, sehingga menyebabkan peningkatan pengetahuan dan kompetensi peserta terkait UKM. Waktu pendampingan yang diberikan menambah kuantitas transfer of knowledge dari pendamping kepada peserta internsip. Pengalaman yang diperoleh pendamping dari pelaksanaan kegiatan UKM puskesmas dapat lebih mudah disampaikan kepada peserta apabila frekuensi pendampingan cukup. Hasil kajian juga menunjukkan bahwa hampir seluruh peserta menyatakan bahwa kompetensi pendamping sudah baik. Kompetensi yang baik menyebabkan materi yang ditransfer dan proses transfer of knowledge berlangsung lebih baik.

Peserta dengan pendamping yang aktif melakukan penilaian terhadap log book dan laporan, serta memiliki cukup waktu untuk membimbing, akan mengalami peningkatan pengetahuan UKM yang lebih tinggi. Hal ini sesuai juga dengan pendapat Notoatmodjo menganai proses belajar. Dalam proses belajar terjadi pengaruh timbal balik antara berbagai faktor, diantaranya subjek belajar, pengajar (pendidik atau fasilitator), metode, dan teknik belajar, alat bantu belajar dan materi yang dipelajari ${ }^{12}$.

$$
\text { Pada pelaksanaan prakteknya, }
$$
peserta internsip akan mendapat pendamping seorang dokter atau supervisor yang memenuhi kriteria tertentu, diantaranya dokter yang masih aktif praktik minimum 2 tahun, bersedia mengikuti pelatihan menjadi pendamping dan bersedia secara aktif melakukan tugas pendamping. Peran pendamping lebih sebagai role model, motivator, tempat berkonsultasi dan juga penilai. Idealnya satu dokter pendamping untuk 5 dokter internsip yang ditempatkan. Dengan internship dokter yang belum memiliki sertifikat kompetensi ini akan bertanggung jawab penuh pada tindakan tindakan yang dilakukan kepada pasien, berbeda dengan co-ass jaman dahulu yang tidak memiliki tanggung jawab langsung terhadap kesehatan pasiennya. Asesmen peserta didasarkan atas tercapainya tujuan Internsip sesuai standar kompetensi dokter layanan primer yang dipahami baik oleh peserta maupun pendamping. Peserta mendapat umpan balik secara teratur, baik dari pendamping maupun dari tenaga kesehatan lain dalam bentuk pengamatan langsung maupun tidak langsung ${ }^{14}$. Pada akhir penugasan, pendamping melakukan penilaian guna memastikan pencapaian program. Terhadap peserta yang telah menyelesaikan seluruh program internsip akan diberikan Sertifikat Internsip yang ditandatangani oleh Ketua Komite Internsip Dokter Indonesia ${ }^{15}$.

\section{Kesimpulan dan Saran}

Secara umum terjadi peningkatan nilai pengetahuan peserta internsip tentang upaya kesehatan masyarakat. Faktor yang menunjukkan perbedaan peningkatan nilai 
pengetahuan tentang upaya kesehatan masyarakat adalah lama puskesmas menjadi wahana, keberadaan puskesmas, keberadaan pusling roda empat, pendamping menilai logbook, pendamping menilai laporan, pendamping memiliki cukup waktu dalam membimbing, dan kegiatan mini project yang diikuti peserta.

Diperlukan dukungan sarana di semua wahana untuk mempermudah akses peserta dalam mendapatkan pengetahuan, optimalisasi peran pendamping dalam membimbing serta peran aktif peserta dalam mendapatkan pengetahuan dan mengembangkan pengalaman.

\section{Daftar Pustaka}

1. Kementerian Kesehatan Republik Indonesia. Undang-Undang Republik Indonesia No. 36 Tahun 2009 Tentang Kesehatan. 2009;111.

2. Konsil Kedokteran Indonesia. Standar Pendidikan Profesi Dokter. Jakarta: Konsil Kedokteran Indonesia; 2012. 1-26 p.

3. Departemen Kesehatan Republik Indonesia. Pedoman Pelaksanaan Internsip Dokter Indonesia. Jakarta: Badan PPSDM Kesehatan; 2009.

4. Achmadi UF. Kesehatan Masyarakat: Teori dan Aplikasi. Jakarta: Rajagrafindo Persada; 2013.

5. Badan Litbang Kesehatan. Laporan Kajian Cost, Output, dan Manajemen Program Internsip Tahun 2015.
Jakarta; 2015.

6. Maeshiro R, Johnson I, Koo D, Parboosingh J, Carney JK, Gesundheit N, et al. Medical education for a healthier population: reflections on the Flexner Report from a public health perspective. Acad Med J Assoc Am Med Coll. 2010;85(2):211-9.

7. Navinan MR, Wijayaratne DR, Rajapakse S. Final-year medical students' perceptions regarding the curriculum in public health. Indian $\mathrm{J}$ Community Med. 2011;36(4):26874.

8. Dysinger WS, Pappas JM. A fourthyear medical school rotation in quality, patient safety, and population medicine. Am J Prev Med. 2011;41(3):200-5.

9. Starfield B. Primary Care and Equity in Health: The Importance to Effectiveness and Equity of Responsiveness to Peoples' Needs. Assoc Humanist Sociol. 2009;33(1):56-73.

10. Saramunee K, Krska J, Mackridge A, Richards J, Suttajit S, PhillipsHoward P. How to enhance public health service utilization in community pharmacy?: general public and health providers' perspectives. Res Soc Adm Pharm. 2014;10(2):272-84.

11. Rachmani KT. Faktor-Faktor yang 
Rofingatul Mubasyiroh, Mieska Despitasari, Harimat Hendarwan, Peningkatan Pengetahuan Upaya Kesehatan Masyarakat pada Dokter Internsip Berdasarkan Faktor Wahana Puskesmas DOI : $10.24853 /$ jkk.14.1.26-38

Mempengaruhi Kinerja Dokter

Internsip (Studi pada Dokter

Internsip Lulusan Universitas Jember

dan Dokter Pendamping di

Puskesmas). Universitas Jember; 2013.

12. Notoatmodjo S. Ilmu Kesehatan

Masyarakat: Prinsip-prinsip Dasar.

Jakarta: PT Rineka Cipta; 2003.

13. Priantono D. Pelaksanaan Internsip di Indonesia. 2013;1(3):1-4.

14. Donovan C, Garnett J. Internship for Dummies. 2018.

15. Konsil Kedokteran Indonesia.

Registrasi Dokter Program

Internship [Internet]. Indonesia;

2010. Available from:

http://www.kki.go.id/assets/data/me

nu/Perkonsil_No._1_Tahun_2010_2

.pdf 